Comparative Philosophy Volume 9, No. 2 (2018): 41-68

Open Access / ISSN 2151-6014 / www.comparativephilosophy.org

https://doi.org/10.31979/2151-6014(2018).090205

\title{
DIALETHEISM, PARADOX, AND NĀGĀRJUNA'S WAY OF THINKING
}

\author{
RICHARD H. JONES
}

\begin{abstract}
Nāgārjuna's doctrine of emptiness, his ideas on "two truths" and language, and his general method of arguing are presented clearly by him and can be stated without paradox. That the dialetheists today can restate his beliefs in paradoxical ways does not mean that Nāgārjuna argued that way; in fact, their restatements misrepresent and undercut his arguments.
\end{abstract}

Keywords: dialetheism, logic, Madhyamaka Buddhism, Nāgārjuna, paradox

Today dialetheists in philosophy of logic argue that the law of noncontradiction can be violated in some paradoxes because some contradictions at the limits of our knowledge are true and that there may be adequate grounds for holding explicitly contradictory beliefs in those cases. Graham Priest $(2002$; 2004) argues that all attempts at closure at the boundaries of thought and of what is knowable in science lead to contradictions - any conceptual process crossing those boundaries results in the paradoxes of self-reference-but that these contradictions in fact state truths, and something contradictory about reality itself renders such contradictory statements true. Thus, there is "cogent inconsistency" (Garfield and Priest 2009, 81).

Jay Garfield, Graham Priest, and Yasuo Deguchi apply contemporary dialetheist ideas to the second- or third-century CE Buddhist Nāgārjuna (beginning with Garfield and Priest 2003). They are not arguing that Nāgārjuna was irrational or confused, but that there are things about reality at the "limits of thought" in the Madhyamaka worldview that cannot be expressed consistently. They explicitly state that Madhyamaka thought is "inconsistent" and that

...Madhyamaka is profound precisely because it dares to go where no philosophers have gone before-or at least with such care: to the limits of being, thought, and

JONES, RICHARD H.: Independent scholar (Ph.D., Columbia University; J.D., University of California at Berkeley), USA. Email: rhjones2488@gmail.com 
language, to face the paradoxes that lie at those limits, and to demonstrate that those and to demonstrate that those paradoxes show that reality itself is paradoxical (DGP 2013b, 396). ${ }^{1}$

But it will be argued here that there is a consistency to Nāgārjuna's thought and that introducing paradoxes into it only muddles his presentation. What he wrote is not inconsistent or paradoxical in content when understood in terms of his overall philosophy. It will be shown that even those of his expressions that are paradoxical in form can be restated without paradox, and thus we cannot conclude that those paradoxes reflect his way of thinking - in fact, nothing in his works suggests that some truths can only be expressed in inconsistent statements.

\section{THE DIALETHEISTS’ BASIC POSITION}

The dialetheists assert that only early Mādhyamikas thought involved contradictions, although they tend to speak of Madhyamaka thought in general since they believe that their position is entailed by how they interpret Nāgārjuna's work (DGP 2013a, 427). But they admit that after the arrival of the Buddhist logicians Dignāga and Dharmakīrti who explicitly endorsed the law of noncontradiction, Indian and Tibetan Mādhyamikas stressed never accepting contradictions (ibid., 429). Nor can they point to any Indian Buddhist commentators who accepted the alleged paradoxes. They must argue that all later Mādhyamikas misunderstood Nāgārjuna (DGP 2013b, 396) and indeed that we had to wait until the twenty-first century when paralogicans came along and started applying their ideas to Nāgārjuna for anyone to see the light. ${ }^{2}$

The dialetheists have formulated new paradoxical statements in a "rational reconstruction" of Nāgārjuna's thought:

- "There are no ultimate truths, and it is ultimately true that everything is empty."

- "Things have no nature, and that is their nature."

- "There are no ultimate truths, and that is one of them" (DGP 2013a, 426). ${ }^{3}$

\footnotetext{
${ }^{1}$ Tom Tillemans $(2009 ; 2013)$ argues for a "soft dialetheism": Nāgārjuna may treat something as real in one place for worldly purposes (i.e., conventional truth) and unreal in another place since it is empty (śunya) of intrinsic nature (svabhāva) (i.e., ultimate truth). That is true, but this should not be considered a form of "dialetheism" since it avoids the key element of the conjoining of two conflicting statements into one paradox - the same aspect of something is not both affirmed and denied at the same time in the same way.

2 The dialetheists also see irresolvable paradoxes in the Prajñāpāramitā literature-e.g., "all phenomena have one nature-that is, no nature" (DPG 2013b, 393). And the Perfection of Wisdom texts does delight in paradoxes. For example, Aștasāhasrikā-prajñāpāramitā 192 states that the nature (prakṛti) of all dharmas is to have no nature. But the paradoxes in the Prajñāpāramitā texts can be resolved and shown to have a nonparadoxical content (see Jones 2012, 220-23), including "Form is emptiness" (ibid., 224-26).

3 To give another example, when Mark Siderits (2008) states "the ultimate truth about tables is that there are no tables!" he needlessly introduces a paradox into a situation that can be stated consistently
} 
They argue that Nāgārjuna actually thought with such inconsistencies. However, the dialetheists admit that Nāgārjuna never made those statements. Nāgārjuna, in fact, only stated things that were completely consistent or that can be explained consistently (possible exceptions are discussed below). Here are consistent restatements that better reflect his thought:

- "There are ultimate truths, e.g., 'Everything in reality is dependently-arisen (pratītyasamutpāda) and empty of anything self-existent (nihsvabhāva), and that "that-ness" (tattva) of phenomena is the ultimate nature of what is real'."

- "The ultimate nature of things in the final analysis is that they have no selfexistence (svabhāva)."

- "That reality is empty of self-existence is an ultimate truth (paramārtha-satya) of the nature of reality as it truly is (yathäbhütam)."

Nāgārjuna never denied that something exists in the final analysis and thus is ultimately real (tattva, paramārtha-satya, dharmatā) nor did he ever state that no statement can express what is ultimately true (contra DGP 2013b, 396).

To claim, as the dialetheists do, that "Things have the intrinsic nature of having no intrinsic nature" would introduce a paradox that distorts the nature of Nāgārjuna's arguments: to him, only things that are self-existent (svabhāva) have a separate existence, and hence have their own intrinsic nature; and thus things that arise dependently upon causes and conditions can have no "intrinsic nature" in that sense. That is, dependently-arisen things do have a "nature" in the everyday sense of having a general nature or characteristic revealed by analyzing them. All dependently-arisen things have the general nature of being impermanent and connected to some other phenomena, but they do not have Nāgārjuna's metaphysically-loaded sense of "svabhāva" of existing independently in its own right without any causes and conditions (i.e., existing as an independent substance). In short, dependently-arisen things are not self-contained "self-existent" realities. ${ }^{4}$

These two senses of "intrinsic nature" that must be distinguished: the general sense of a something's properties and Nāgārjuna's restrictive metaphysically-loaded sense of self-existence. We can talk about the nature of something in its final analysis without requiring that any metaphysically entities-i.e., without self-existent substances (svabhāva) Consider this dialetheistic claim:

(if a little cumbersomely) without one: "The ontologically correct truth about the entities that we conventionally call 'tables' is that there are no such self-existent, independent entities but only empty phenomena." So too, we must reject his paradox: "The ultimate truth is that there is no ultimate truth" $(1989,213,247 ; 2008,127$ - there is an ultimate truth about the nature of phenomenal reality: it is empty of any self-existent entities.

4 Nāgārjuna is attacking the earlier Abhidharmist view of svabhāva. For the Abhidharmists, "svabhāva" meant "self-nature" - i.e., each factor of the experienced world (dharma) has a unique and independent nature-but all factors are still conditioned and temporary. Nāgārjuna apparently mischaracterized their view by switching the focus of svabhāva to also include self-existence (see Jones 2014, 171-177). 
- "emptiness [śunyatā] has no intrinsic nature, and...this is its intrinsic nature."

(DGP 2013b, 396). ${ }^{5}$ This needlessly introduces an apparent paradox by combining the two senses of "intrinsic nature." By playing on the ambiguity, it becomes a paradoxical way of stating a simple point: what is dependently-arisen does not exist as a self-existent substance (svabhāva in the metaphysically-loaded sense). That is:

- "Things are empty of a self-existent substance (svabhāva), and that is their reality in the final analysis."

However, to say as the dialetheists do, that "emptiness has no svabhāva, and that is their svabhāva" is simply wrong: what is empty of svabhāva does have a general "nature" or "property" (being dependently-arisen), but it does not have svabhāva in Nāgārjuna's more restricted sense of having a self-existent substance-for Nāgārjuna, only what is real (sat), i.e., eternal and unchanging, is self-existent and thus has a selfexistent substance (svabhāva) (MK 24.33, 24.23, 22.24; VV 67; SS 21). Thus, what is empty of svabhāva is not self-existent and does not exist by any svabhāva-like substance.

The dialetheists" mistaken premise here is that "ultimate reality" must be "that which has svabhāva" (DGP 2013a, 430) rather than merely what exists in the final analysis (paramārtha). But according to Nāgārjuna, something does exist in the final analysis and thus is "ultimately real": dependently-arising phenomena of the phenomenal realm-being free of independently-existing substances is the "thatness" (tattva) of things in the final analysis. To be empty of self-existence does not mean nonexistent. He is offering a "middle way" ("madhyamaka" means "middlemost" in Sanskrit) between what is eternal and unchanging (sat) and what is completely nonexistent (asat) — phenomena do exist, but they arise dependently and thus are empty of independence and self-existence. He never denied that "dependentarising" is an indicator of the true nature of things. That is, we can speak of what is "ultimately real" for Nāgārjuna, but we cannot restrict the phrase to only what is selfexistent. His metaphysics dictates otherwise: phenomena are not eternal and unchanging (i.e., sat), but they nevertheless do exist in the final analysis - it is only that they exist in a different manner (existing dependently). Nor is there anything paradoxical in denying that phenomena are neither real (sat) nor totally nonexistent (asat) if these two categories do not exhaust all ways of being.

In sum, Nāgārjuna (and later Indian Mādhyamikas) claimed that the nature of things in the general sense is to be dependently-arisen. But he does not claim that they have a self-existent essence (svabhāva) that would make them independent of

\footnotetext{
${ }^{5}$ Concerning what is empty, they say: "ultimate truth and conventional truth constitute a mutually exclusive and exhaustive partition of the domain of truth. But the ultimate truth is that there is no ultimate reality, and ultimate truth, for example the truth that all phenomena are empty of intrinsic nature, is the truth about ultimate reality. There is hence no truthmaker for ultimate truth, and hence no ultimate truth. But that is an ultimate truth" (ibid., 395). They believe that both Nāgārjuna and Candrakîrti "are committed to the truth of this contradiction" (ibid.).
} 
everything else. Thus, the dialetheists' claim "What is empty has no intrinsic nature, and...this is its intrinsic nature" can be unpacked as meaning one of two things:

- "What is empty has no intrinsic nature (svabhāva), and that is its general nature in the final analysis."

- "What is empty has no intrinsic nature (svabhāva), and that is its intrinsic nature (svabhāva)."

The first restatement is true and not paradoxical and reflects Madhyamaka thought. The second is indeed paradoxical, but it is untrue in Nāgārjuna's philosophy: what is empty of substance has no self-existence. He never stated "it is of the intrinsic nature [svabhāva] of things to be empty" (contra DGP 2013a, 431). To ascribe "selfexistence" to what is dependently-arisen would violate his philosophy at its core. The that-ness (tattva) of reality in the final analysis (paramārtha) is free of "a self-existent substance" or "self-existence" or any other intrinsic nature (svabhāva). Nothing in Nāgārjuna's corpus suggests that he would say "The absence of svabhāva (i.e., emptiness) is the substantive core (svabhāva) of things." ${ }^{\prime 6}$ But to dialetheists, by being empty of self-existence something has the intrinsic nature of having no intrinsic nature (DGP 2013b, 395). However, only by the sleight of hand of relying upon the ambiguity of the term "intrinsic nature" as either the general category of an "ultimate reality" (i.e., what exists in the final analysis) or Nāgārjuna's technical sense of "selfexistence" as independent substance can the dialetheists argue for their paradoxical restatements. Relying on an ambiguity is not only sloppy by our standards, it violates a classical Indian rule of debate.

\section{THE LOGICAL STRUCTURE OF NĀGĀRJUNA'S ARGUMENTATION}

Nāgārjuna does not violate any of the usual laws of logic and his use of logic is very evident in all his texts. Most importantly, he relies on the basic rules of logic to make his arguments-Nāgārjuna's method of arguing fails if the contrast between $x$ and not- $x$ is not exclusive and exhaustive since his conclusion of emptiness as the only alternative to anything existing by svabhāva would then not follow. Thus, if Nāgārjuna accepted that contradictions could state a truth in some instances, as Garfield and Priest (2003) contend, then his arguments would fail since the contradictions again would not be grounds to accept emptiness. That is, the general way Nāgārjuna gets to emptiness is to eliminate self-existence rather than advancing independent positive arguments for accepting emptiness (but see MK 13, 24), and so he has to remove all logical possibilities for self-existence-if a contradiction

\footnotetext{
${ }^{6}$ MK 22.16 states: "Whatever is the essence (svabhāva) of the Buddha, that is the essence of this world. But the Buddha is without any essence, and this world is without any essence." This can be interpreted along those lines: whatever is the general nature of the Buddha is also the general nature of this world-i.e., to be without any self-existence. That is, it is only a statement of the emptiness of everything.
} 
concerning self-existence affirms a truth, his arguments would fail. (The dialetheists realize that if contradictions are acceptable for Nāgārjuna's own position but that the logical contradictions he points out in his opponents' positions decisively refute them, then his opponents could rightly ask for reasons for this special pleading.)

Consider two basic laws of standard Aristotelean logic: the law of noncontradiction (nothing can be both $x$ and non-x), and the law of the excluded middle (everything is either $x$ or non- $x$ ). ${ }^{7}$ Most people believe these laws apply to all thought - e.g., how can someone believe that a statement is both true and false? How can a self-contradictory statement be intelligible? And if we examine Nāgārjuna's arguments, we see that he implicitly relies on both laws. (He never discussed logic, i.e., theories of what is a valid inference or deduction.) And it should be noted that, unlike Western philosophers, Nāgārjuna speaks of a conflict of properties, not statements - i.e., he states that something cannot be or have properties $x$ and non- $x$ or that $x$ and non- $x$ cannot be in the same place at the same time. His focus is on the world, not the logic of statements. For example, in MK 8.7: "'real' and 'unreal' are mutually contradictory (paraspara-viruddha) - how could they exist together simultaneously?" (see MK 7.30, 21.3, 25.17, 25.25-27; RV 4). Obviously, an entity (bhāva) and its absence (abhāva) cannot exist together (MK 25.14). ${ }^{8}$

Many of Nāgārjuna's arguments proceed on the basis that $x$ and not- $x$ are mutually exclusive and that there is no third possibility. So too, he implicitly utilizes the law of the excluded middle in MK 2.15: "A mover is not stationary, just as a nonmover is not stationary. And other than a mover or a non-mover, what third possibility is stationary?" (see MK 1.4, 2.8, 3.6, 4.6, 6.10, 8.1, 21.14; VP 50, 58, 59). He also relies upon the standard inferences of modus ponens and modus tollens (see Jones 2014, 159).

However, not all cases of $x$ and not- $x$ in Nāgārjuna's works are like that. In some instances, $x$ and not- $x$ are connected and not exhaustive - in particular, "bhava" and

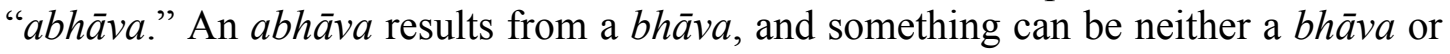
an abhāva-e.g., nirvāna (RV 42; SS 25). Thus, denying the existence of an entity (bhāva) in no way logically requires affirming the absence of a real entity (abhāva). So too, the contrast between "existence (sat)" and "nonexistence (asat)" as he defines the terms is not exhaustive but only shows the extremes: existence in the sense of sat is eternal existence (and hence unceasing), and nonexistence is total nonexistence (and hence unarisen) - thus, something that comes into existence or did exist but comes to an end does not fall into either category. But what he wants from this is that

\footnotetext{
${ }^{7}$ Priest (2002: 5; 2006, 94-95) contends that there have been no defenses of the law of noncontradiction since Aristotle's worth mentioning and that Aristotle's arguments for it are not convincing. This may be true, but the important point for this article is that Nāgārjuna was implicitly following the law in his arguments. To do away with the law would be to do away with his method of argumentation.

${ }^{8}$ In Nāgārjuna's philosophy, even the basic law of identity-x is $x$ "- is problematic since impermanent phenomena are constantly changing: what was $x$ is no longer the same now. He would probably respond that this law could only apply to what is self-existent-only such permanent realities could remain identical to themselves.
} 
the fact that we see things arise eliminates "nonexistence" and the fact that we see things cease eliminates "existence." Thus, he wants a third ontological category between the extremes of eternal existence and total nonexistence-what is "empty" of svabhāva.

The dialetheists may reply that they of course accept this - they are not claiming that Nāgārjuna's arguments are all illogical, but only that he accepted some instances of paradoxes. However, this misses the point: logic is at the center of Nāgārjuna's argument. Moreover, in no place did he affirm an irresolvable paradox. This can be seen by looking at the structure of his arguments and some apparent exceptions to consistency.

\section{NĀGĀRJUNA'S METHOD OF ARGUMENT}

Nāgārjuna's primary means of argumentation is to point out that there is a conflict between our everyday experience of change in the world and the alleged permanence in the svabhāva metaphysics (e.g., MK 13.3-4). This is not a scientific analysis of how things work or the invocation of mystical experiences but simply an appeal to the obvious: the changes that we see in our everyday experiences. A second means involves the interconnection of phenomena (e.g., "cause" and "effect," "fire" and "fuel," or "moving" and "a mover") or the relation between an entity and its properties (e.g., an "impassioned person" and "passion"). According to Nāgārjuna, if concepts for these are connected then so is what they conceptualize (e.g., MK 6.1-2), and so they are not independently real but dependently-arisen.

His overall method in his discussions of his opponents' positions, especially in the Vigrahavyāvartanī, is this: he starts with what he sees as his opponents' tenets concerning self-existence and then shows how these premises logically lead to contradictions with either our experiences or the concepts involved. For example, he claims that what exists by self-existence can only be either identical to something else real or totally distinct; hence, if the oneness of two entities or their absolute difference is not possible (e.g., a cause and its effect such as milk and butter [MK 20.19]) because we see otherwise, then the entities are empty of self-existence, and therefore the entities are not real (sat). Thus, the initial premise - that things exist by their own power and so is existing by itself, i.e., "self-existent"-must be wrong. Self-existence is not found in the world of our experience and so is not "established" (siddha). Thus, emptiness then follows automatically since he sees this as the only alternative to a svabhāva metaphysics-i.e., he does not argue directly for emptiness but shows that the only alternative he sees (i.e., self-existence) must be rejected. In this way, he need not present positive arguments for a thesis or use emptiness as a reason but only presents problems with its only alternative. Nor does he use emptiness as a reason or a premise in its own right. In short, he does not argue for śunyatā but only against svabhāva.

Arguments based on the interconnection of concepts proceed in that manner. Our conceptualizing mind operates by making distinctions, and hence if an entity being referred to does not exist then neither does its opposite and so there is no real 
distinction to be drawn. For example, if there is no self-existent mover, then there is no mover who could rest; but since there is no mover, there can be no non-mover either who could rest (MK 2.15) since the very idea of a "non-mover" depends upon there being a real "mover." What is "unpleasant" depends upon what is "pleasant" for its label and vice versa; so no real entities are involved (MK 23.10-11). So too, if there is no self, there is no non-self, and so forth. In particular, if there is nothing that is not empty, then there is nothing empty to contrast it with (MK 13.7).

His argument in the abstract is simple. Whatever topic we are talking about is either real (sat) or unreal (asat). If it is real (i.e., self-existent), then it is eternal and unchanging and cannot do anything - it cannot be a cause or effect, cannot be produced or cease, cannot move or change, cannot have conditions, and so forth. In short, it is self-existent and not affected by anything else, nor can it affect anything else that is real. On the other hand, if something is unreal, then it is not a reality that can be a cause, have a characteristic, and so forth. There is no third possibility if we remain thinking in terms of "self-existence." Thus, the field is cleared of alleged "entities," and only emptiness remains. Reality as it truly is (yathäbhütam) has no real (sat) parts, and so it can work precisely the way we see the phenomenal world actually working.

Thus, Nāgārjuna advances no counter-metaphysics to his opponents' that he has to defend. Rather, he simply shows that errors follow from their metaphysical beliefs. From that demonstration, he believes emptiness follows by default since he sees it as the only alternative to self-existence. This approach does not compel him to accept any counter-proposition: he need not defend any alternative if he only shows that there are flaws in another's position. ${ }^{9}$ And one can point out problems in someone else's position without defending a counter-position. For example, you could point out an error in my adding a column of numbers without advancing what you think is the correct sum. (But as discussed below, this does not mean that Nāgārjuna did not himself hold metaphysical beliefs connected to emptiness and dependent-arising.)

The important point to note here is that none of these arguments would proceed without the contrast between $x$ and not- $x$ being exclusive and exhaustive. Introducing paradoxes as the dialetheists do would vitiate all of them.

\section{THE FOUR OPTIONS}

One apparent paradox involves a technique that Nāgārjuna employs, although he never uses the word in his writings: the "four options" (catuș-koți) (MK 12.1, 18.8, 22.11-12, 25.15-18, 25.22-23, 27.13, 27.20; see RV 106, 115). Here he rejects: (1) $A$ exists; (2) $A$ does not exist; (3) $A$ both exists and does not exist; (4) $A$ neither exists nor does not exist. ${ }^{10}$ Doesn't the denial of the first option logically commit the holder

\footnotetext{
${ }^{9}$ Nāgārjuna exemplifies a category of debate in classical India in which one can deny a thesis without admitting a counter-thesis (prasajya) (see Matilal 1998).

${ }^{10}$ This is not a fixed form-sometimes we have to put a number of verses together to get all four options (MK 25.4, 7, 11, and 15); often there are only the first three (MK 1.7, 2.24-25, 5.6, 8.9-11, 21.13, 23.20; RV 37; SS 4, 44; VP 4, 51, 56, 73). Indeed, the very first verse of the Kärikā can be seen
} 
to the second? How can someone deny that something neither exists nor does not exist? Doesn't the denial of the fourth option make Nāgārjuna look as if he is denying the basic law of non-contradiction?

Philosophers have expended a lot of ink applying symbolic logic to these denials to try to see how they are not paradoxical. ${ }^{11}$ But efforts to apply symbolic logic to the four options miss the point: Nāgārjuna is trying to state that we cannot think of anything in terms of self-existence. That is, he is arguing that we cannot think intelligibly in terms of isolated, substantive "self-existent" realities. He uses the form of the four options simply to try to cover all positive and negative possibilities - i.e., he is saying there are no other options. He wants to cover all possibilities so that all claims involving svabhāva in different contexts are eliminated, and thus by default only emptiness remains. This approach obviously does not work unless it exhausts all logical possibilities - only then will emptiness be the only alternative left standing.

But this is possible only if the four options presuppose the laws of noncontradiction and excluded middle as the way to exhaust all possibilities. And the "four options" approach can be shown to be logical and free of paradox easily enough without resorting to technical rules. For example, if someone asks what color the number 4 is, we might say "It is not blue, not a color other than blue, not both blue and another color, nor neither blue nor another color." All four denials are true and consistent since numbers do not have color. Each denial does not logically commit one to affirming another position on a color for four. We might think that the last option applies - "neither blue nor another color"-but in Nāgārjuna's framework, as long as we are thinking in terms of color we are on the wrong track regarding the nature of numbers. So too, with the four options regarding whether something "exists": to Nāgārjuna, only something that is self-existent can exist or not exist, and so as long as we are thinking of phenomena in terms of "self-existent realities," we do not understand the true nature of reality but are still thinking along conventional lines and thus in terms that cannot apply to the true nature of reality. To use the early Buddhist analogy, it is like asking in which direction a flame goes when a fire goes out - any answer shows that we are thinking along the wrong lines (i.e., presupposing that the flame still exists). So too, for Nāgārjuna only an entity existing by selfexistence could be the subject of the four options, and the denial of all four options is consistent if there are no self-existent realities.

In sum, the key to this technique is denying the hidden presupposition of the four options: that things exist by svabhāva. All he is saying is that the subject to each option does not exist. In addition, he treats the fourth alternative as a type of thing-if nirvāna is neither an entity nor a non-entity (RV 42; SS 25), then it cannot be a "neither-an-entity-or-a-non-entity" (MK 25.16). Such an entity is the kind of entity that contrasts with the third option: if we can establish something that is an " $x$-and-

as the four options since "no cause" can be most easily interpreted to mean "neither self-caused nor caused by another" (see VV 51).

${ }^{11}$ I too am guilty of applying modern symbolic logic to Nāgārjuna's thought (Jones 1993, 260-61 n. 6). But this was done not to claim that this is how Nāgārjuna actually reasoned - it was only to show that his argument could be shown to be logically valid by employing shorthand modern symbolic forms. 
non- $x$," then we can establish what contrasts with it-something that is "neither- $x$ nor-non- $x$ " (e.g., MK 27.18, 27.28). Conversely, if we cannot establish one, we cannot establish the other because of their interconnection. If we cannot establish $x$ as real, then we cannot establish its absence (i.e., a not- $x$ ) or a conjunction of the two ( $x$ and-not- $x$ ) or the absence of that conjunction (not " $x$-and-not- $x$ "). The third option can be established only if the first two can be (MK 5.6, 12.9), and the fourth could be established only if we could establish the third alternative (MK 25.15, 27.18, 27.28). Thus, since $x$ is not real to begin with (since nothing exists by self-existence), none of the other options are possible. In addition, Nāgārjuna would add that we must reject the third option because $x$-and-not- $x$ would be a composite of opposites but opposites cannot exist together in the same place (e.g., light and dark [MK 25.14]). Thus, nothing more is needed to explain the four options than Nāgārjuna's general method of interconnecting terms.

Another apparent inconsistency occurs in MK 18.8 where the four options are not denied. Nāgārjuna states: "The Buddha's progressive teaching (anuśāsana) is this: everything is real; or everything is not real; or everything is both real and not real; or everything is neither real nor not real." The dialetheists treat this as a paradox (DGP 2008,397 .) The third option appears to violate the law of the non-contradiction and the fourth the law of the excluded middle. But the prefix "anu-" means that the teaching (śāsana) is not the same for all listeners, but adjusted for different ones (see RV 394-96, YS 30). Thus, the Buddha might have taught "everything is real" to beginners, "everything is unreal" to those with some advanced training, and so ononly the fourth option would be the final truth since everything in Nāgārjuna's metaphysics is neither real (sat) nor unreal (asat). Another way to make this verse consistent (following Candrakīrti's commentary) is to invoke the "two truths" doctrine: "Every entity is real from the conventional point of view (MK 7.24), and every entity is unreal from the ultimate point of view (MK 15.4); every entity is both conventionally real and ultimately unreal; every entity is neither ultimately real nor conventionally unreal." Entities are not real from the point of view of ultimate truth, but they do exist in the conventional sense, and Nāgārjuna can affirm both claims without contradicting himself since they are about different matters- there is no genuine paradox since the same claim is not both affirmed and denied in the same context. It is like the analogy of misperceiving a rope as a snake: it is indeed both totally real (the rope) and totally unreal (the snake) at the same time. ${ }^{12}$ But there is no suggestion of genuine paradox - that the misperception can be stated paradoxically does not mean that we think the world is constructed inconsistently or that we must think about the situation inconsistently. Garfield and Priest $(2003,2)$ agree that this apparent inconsistency can be rewritten without a paradoxical form. But this means that the form does not reflect consistent thoughts, and thus an appeal to dialetheistic logic is not needed.

\footnotetext{
${ }^{12}$ The analogy is more associated with Advaita Vedānta, but it may have been introduced by the Mādhyamikas, depending on the age of a certain text (see Jones 2011, 5-8).
} 
Thus, the apparent paradoxicality of Nāgārjuna's treatment of the four options can be explained away. Indeed, by focusing on possible logical matters within the four options, philosophers are missing the import of the arguments - in short, they miss Nāgārjuna's actual reasoning entirely. Nor is there anything about reality that is inherently paradoxical from Nāgārjuna's point of view in these passages. The question is not whether a given verse is contradictory in form, but whether Nāgārjuna's thought behind it is consistent or not. That is, can we consistently paraphrase what Nāgārjuna states without doing violence to his thought? If so, then the fact that the idea can also be stated inconsistently is irrelevant to how he may have been thinking. ${ }^{13}$ Instead, we must look at more of his work to see why he wrote what he did, and if the overall thought is consistent, then there is no reason to conclude that his thinking on the four options is an exception and paradoxical even though the form of its statement is. If so, there is no need to invoke a paraconsistent logic in any way to understand what he is saying or draw the dialetheists' conclusion about paraconsistent truths.

\section{THE TWO TYPES OF TRUTH}

Many of Nāgārjuna's alleged inconsistencies disappear through his use of "two truths." In the MK 24, he wrote:

[8] The buddhas' teaching of the doctrine rests upon two categories of truths: truth based on worldly conventions and truth from the highest point of view. [9] Those who do not discern the distinction of these two categories of truths do not discern the profound truth in the teachings of the buddhas. [10] Without relying upon worldly convention, the truth from the highest point of view cannot be taught. And without reaching the truth from the highest point of view (paramārtha), nirvāna cannot be achieved.

In Nāgārjuna's ontology, the phenomena of the experienced world are empty of selfexistence and thus not real (sat) but exist dependent upon other phenomena - that is the final analysis of reality as it truly is (tattva, yathäbhītam, dharmatā). That is, phenomena exist dependent upon other phenomena and thus are neither real (sat) nor nonexistent (asat) because no self-existence (svabhāva) is involved; rather, they fall in a category (dependently-arisen phenomena) that is outside anything either having self-existence or being nonexistent. This leads to a clear picture of what he states about ultimate and conventional truth. In fact, the two types of truth play a central role in Nāgārjuna's arguments (see MK 24.36; VV 28; SS 1, 69-73; YS 30-33). Their

\footnotetext{
${ }^{13}$ One implication of Zeno's paradoxes is that they show that we can conceptualize perfectly ordinary everyday events in such a way that makes them appear paradoxical or impossible-e.g., that the rabbit could never catch the tortoise in their race. The world then appears paradoxical if we could not state what we see free of inconsistencies. But the dialetheists claim that Nāgārjuna thought in a paradoxical manner and could not state his positions without paradox, not simply that his consistent claims can also be stated paradoxically if we choose to do so.
} 
importance is fixed by verse 9: this is the only place in his philosophical corpus where he points out the "profound truth" of the buddhas' teachings in this way.

Ultimate truths (parama-arthatas) are truths about things in this world from the point of view of ultimate ontological status, while conventional truths (samvrti-satya, loka-samvrti) are about what counts as real depending on our conventions. Conventional truths are determined by worldly practices and conventions (vyavaharas), not just language. In the more informal Ratnāvalì (360-365), Nāgārjuna contrasts what is "in fact real" or "really the case" (arthatas) with what is "worthless" or "pointless" (vyarthatvam). Ultimate truths state what in the final analysis is the ultimate ontological status of whatever phenomenon is being discussed. These truths are not open to any further ontological analysis, while the subjects of conventional truths are open to a deeper ontological understanding. In short, ultimate truths are about the ontological status of such phenomena. The two classes of truth are not the same, and ultimate truths cannot be reduced to conventional truths, even though they rely on conventions to be stated, because of this difference of frames of references. Ultimate truths conceal nothing. Ultimately, worldly phenomena are void of selfexistence and arise dependently - no deeper truth about their status or a deeper ontological understanding is possible. Any truth stated in terms of entities is only a conventional one. MK 1.1 on entities not arising is a conventional truth since it is about the relation of entities; the ultimate truth is that there are no real entities. So too, the role of entities in the "four options" makes their denial a conventional truthfrom the ultimate point of view, Nāgārjuna neither negates nor denies the four options (e.g., MK 22.11) since only what is real (sat) through self-existence can be negated or denied, and so emptiness does not exist as a real entity.

Conventional truths accept our worldly categories, but ultimate truths do not. However, ultimate truths do depend on our conventions (MK 24.10, VV 28 Comm.): without recourse to our conventions, these truths could not be taught or even stated. But an ultimate truth can be stated without reference to entities-e.g., "The that-ness (tattva) of reality is empty of self-existence and is dependently-arisen." Dependentarising is affirmed, and according to Nāgārjuna it only works if things are empty (SS 71). Beyond that, Nāgārjuna has little to say about the nature of reality as it is independent of our conventions (tattva, yathābhütam, dharmatā). MK 18.9-11 states:

[9] The characteristic of what is actually real is this: not dependent upon another, peaceful (śanta), free of being projected upon by conceptual projections (aprapañcita), free of thoughts that make distinctions, and without multiplicity (anānārtha). [10] Whatever arises dependent upon another thing is not that thing, nor is it different from that thing. Therefore, it is neither annihilated nor eternal. [11] Not one, not diverse, not annihilated, not eternal - this is the immortal teaching of the buddhas, the guides of the world.

In sum, all that can be stated about the ultimate nature of reality is that it is filled with dependently-arisen phenomena and thus is free of distinct, self-existent entities. (Note that Nāgārjuna does not mention the that-ness of reality being empty-emptiness only 
comes up in the context of possibly self-existent realities.) He suggests nothing more positive about the nature of reality as it truly is than that.

Within this framework, Nāgārjuna can maintain both the supremacy of emptiness and also all conventional matters without paradox. All phenomena are empty, but the world is still a world of functioning plants and animals, tables and chairs, even if there are no discrete, self-existent entities; and conventional truths about things' attributes and interactions can be made. To Nāgārjuna, the world of discrete phenomena is only a matter of conventions (RV 114). What is real from a conventional point of view is discrete and permanent (and hence self-existent); from the ultimate point of view, what is real is empty of anything that could give entities selfexistence. Thus, he can negate or deny his opponents' claims about real entities from the conventional point of view, even though there is nothing real (sat) to negate or deny from the ultimate point of view (VV 69). This sometimes leads to Nāgārjuna affirming something from a conventional point of view, or assuming some phenomenon to be conventionally real, and elsewhere denying the same thing from an ultimate point of view. In the conventional sense, there are entities, properties, relations, and processes. So does a table exist? There are two answers depending on the context. A table exists conventionally as a functioning unit but not ultimately (since it is not a self-existent reality). No entities exist in the ultimate sense, but the table does exist conventionally in a way that a unicorn does not - there is something there (a that-ness [tattva]) once we remove the concepts that we use to group phenomena for our convenience. So too, veridical perceptions reveal something about reality that delusions and optical illusions do not, even while they are erroneously framed in terms of self-existent entities.

The ultimate truth of the true ontological status of conventional entities does not deny or negate conventional truths about the relation of those non-self-existent conventional entities. Thus, conventional truths are truths, and Nāgārjuna never denies that there are conventional truths - such truths simply do not state the correct ontological status of things since they ostensibly treat phenomena as "real" (selfexistent) entities. Nor is there any paradox in claiming both that we can use the word "chair" to refer to a temporary configurations of parts that is functioning as a unit at present and that there are no timeless, eternal, permanent, unchanging self-contained entities called "chairs" in the world-both the conventional truth about chairs as existing and the ultimate truth about the absence of anything permanent and independent in them can be affirmed at the same time as long as the contexts of the two claims are recognized. Again, there is no genuine paradox here since statements are made in different contexts and thus do not contradict each other.

The dialetheists realize that their theory requires the rejection of the distinction of ultimate and conventional truths: for dialetheists "[ $\mathrm{t}]$ here is no ultimate truth" (DGP 2013a, 430). But this immediately raises a red flag. Nāgārjuna clearly emphasizes the distinction of conventional and ultimate: "Those who do not discern the distinction of these two categories of truths do not discern the profound truth in the teachings of the buddhas" (MK 24.9). Dialetheists claim that Nāgārjuna contradicts himself by collapsing the two truths into one in MK 24.18-19: since everything is 
empty, there is no "ultimate reality" and therefore no "ultimate truths," and so all truths must be conventional (e.g., Garfield and Priest 2003, 10). That we can speak of "ultimate reality" was discussed above. Moreover, in saying "Whatever is dependently arisen, we call "emptiness," Nāgārjuna is expressing the ultimate status of the phenomena realm - this is not a conventional truth, nor did Nāgārjuna say it is. Once again, the dialetheists are trying to create a paradox where there is none. According to the dialetheists, that reality is empty of self-existence becomes a conventional truth even though nothing Nāgārjuna actually states remotely suggests that. That they must collapse the very idea of two truths should be sufficient grounds to conclude that they are not expounding Nāgārjuna's thought at all. The context in which a truth-claim is made remains vital, and without the two types of truths he would indeed be contradicting himself. However, with the truths being stated in two different frameworks, one can consistently affirm a claim in one context and deny it in another where a different sense of "is" or "exists" is utilized. Thus, the "two truths" approach saves the world from being declared ultimately unreal or nonexistent (only the idea of self-existent entities is faulty) while making impermanence and dependent-arising central to the nature of the world.

\section{LANGUAGE AND ULTIMATE TRUTH}

An "ultimate truth" is a statement that correctly states how things in the final analysis really are. But in order to generate paradoxes, the dialetheists claim that Madhayamaka thought is "full" of ultimate truths (Garfield and Priest 2003, 11) but that these truths are not statable (e.g., DGP 2013a, 426). Thus:

There are no ultimate truths. As we put it before: "Ultimate truths are those about ultimate reality. But since everything is empty, there is no ultimate reality. There are, therefore, no ultimate truths. We can get at the same conclusion another way. To express anything in language is to express truth that depends on language, and so this cannot be an expression of the way that things are ultimately. All truths, then, are merely conventional" (DGP 2008, 399).

In short, since everything is empty, there is no ultimate reality and thus no ultimate truths.

However, simply because there are no self-existent realities does not mean that another type of metaphysics of "ultimate reality" is not possible-i.e., there may be another metaphysics of what is real and irreducible in the final analysis. And according to Nāgārjuna, the phenomenal world may be empty of self-existence and yet still exist in the final analysis even if it is not real (sat) in Nāgārjuna's technical terminology. There may not be any set of discrete, self-existent entities, but there still is a reality of dependently-arisen phenomena apart from svabhāva in Nāgārjuna's metaphysics - what he refers to usually as "tattva." That is the ultimate reality of the 
phenomenal world. ${ }^{14}$ The dialetheists have to twist the plain meaning of ontological terms related to what is ultimately real- "tattva," "dharmatā," and "yathābhütam"to permit contradictions about the final nature of reality into Nāgārjuna's thought. As discussed above concerning the phrase "ultimate reality," denying a metaphysics of self-existent entities (the ontology of $s v a b h \bar{a} v a$ ) does not entail denying all final ontologies of how the world is independent of our conventions.

Nowhere does Nāgārjuna state that ultimate truths are inexpressible or that anything expressed in language is conventional. Rather, for Nāgārjuna ultimate truths could be stated. Consider this claim:

- "The that-ness (tattva) of reality is empty of self-existence (svabhāva)."

That is an absolute truth. It is not a conventional truth but an accurate statement about the ultimate state of things in their final analysis and is not open to any further qualification. In fact, the ultimate truth (paramārtha) consists of the teaching of emptiness (SS 69). Our conventions must be used to state ultimate truths (MK 24.10; VV 28), but these truths are not thereby reduced to conventional truths - an ultimate truth still states something ultimately true about the ontological status of things that is not subject to any further revision.

Nothing in Nāgārjuna's philosophical corpus justifies claiming that ultimate truths are unstatable or that from the highest point of view saying "Reality is empty of self-existent phenomena" is inadmissible because there are no real referents. Nāgārjuna rejects the "realist" view of language in which words must mirror a distinct reality to be meaningful. ${ }^{15}$ For him, words and statements cannot correspond to reality as it really is because reality is not cut up into distinct objects and thus there are no "real" (self-existent) referents for our words (VP 53). His opponent in the Vigrahavyāvartani accepts such a theory (VV 9): "there is no name without an object as a referent." But Nāgārjuna in his response (VV 57-58) rejects that names are "real." 16 Rather, his theory is that dependently-arisen names refer to dependentlyarisen phenomena - neither are "real (sat)" but still function - in fact, according to Nāgārjuna words only function if there are empty of self-existence. Thus, he would have rejected such mirroring for truths from the ultimate point of view since they are

\footnotetext{
${ }^{14}$ Nor should we view Nāgārjuna through the lens of Western metaphysics of transcendent realities: what is ultimately real transcends the conventional point of view, but Buddhist insight is into the phenomenal realm, and ultimate ontological truths are about the same phenomenal realm as conventional truths, not about an alleged transcendent reality.

15 On the "mirror-theory" of language, see Jones 2016, chapter 6. The danger here is that the unenlightened will take any term referring to something_- "dharmas," "nirvāṇa," "emptiness"—as necessarily referring to something independently real (sat) and thus existing by self-existence (svabhāva).

${ }^{16}$ Thus, Nāgārjuna is an anti-realist when it comes to language: the that-ness (tattva) of reality cannot be mirrored in language since reality is not cut up into distinct parts that correspond to different discrete words. However, he is a realist in the everyday metaphysical sense of there being a reality that exists independently of out conceptualizations, although he has little to same about the nature of that reality (e.g., MK 18.9-11).
} 
no "real" discrete objects in the world for our words to mirror (see VP 73 Comm.). However, what he writes does not justify concluding that he rejects truth-claims about his ontology of reality as the that-ness (tattva) of dependently-arisen phenomena. Thus, truths about reality as it truly is can be stated even if there are no distinct, selfexistence real (sat) entities.

The problem for Nāgārjuna is not language per se, but our mental discriminations (vikalpa) and projections (prapañca) (MK 18.5, 18.9, 22.15, 25.24). Language, like all phenomena, is empty of self-existence, but it can be used to point out the nonexistence of self-existence, just as an illusory person can refute the existence of an illusory person he has himself created (VV 23, 27) - if we did not have the illusion of "self-existence," we would not need the illusion of "emptiness." "Empty words" can function like every other empty phenomena. However, our mental fabrications can generate in the minds of the unenlightened a false world of multiple entities. Nevertheless, Nāgārjuna never gives a blanket condemnation of all language while offering emptiness as the way to still the mind of vikalpa and prapañca. In fact, all Nāgārjuna states concerning language relates to three things. First, no real referents exist in the world for words to denote-names and what is named are entities and thus do not exist from the ultimate point of view (VP 73 Comm.). Second, concepts operate by contrasts, and thus pairs of related concepts are interdependent and hence empty. And third, all statements are empty of self-existence, but they still can function (e.g., VV 21-22 Comm., 57 Comm.).

Because everything is empty, there is a problem even referring to "selfexistence" or "emptiness." To have a concept for $x$, we need something real non- $x$ to contrast with it. Nāgārjuna would also add that non- $x$ is derived from $x$; so without a real $x$ there can be no not- $x$. Without such a contrast, we would never have a reason to make up a concept. For example, if the universe were entirely blue, we would see no contrasting color and so we would have no word "blue" to distinguish the color of the universe from other colors. Arguably, the word "blue" would have no meaning if we could not contrast it with something and thus have something specific to apply it to. (Hence philosophers' trouble with the concept of "being." See Jones 2016, 176.) And since there are no self-existent things, how can there be the opposite (i.e., empty things) either? Or if nothing is permanent, what could we call "impermanent" (MK 23.15-16, 27.20)? Or if there is nothing real that is conditioned, there is no "unconditioned" thing either (MK 7.33). Moreover, under the mirror-theory, terms cannot apply if there is nothing real (sat) to denote. Thus, if there are no self-existent things, then there is no reality that could be empty, and so no reality to contrast with such things. And even calling what is empty "something" in Nāgārjuna's eyes means we are still thinking in terms of self-existence.

This means that what is real is inexpressible from the conventional point of view of self-existing entities. Hence, the Buddha is the "silent one (muni)" who did not teach anything real (self-existent) (MK 22.3-4, 25.24) despite all of his discourses. After a passage on prapañca and vikalpa, Nāgārjuna states that when the domain of the discriminating awareness (citta) has ceased, then what can be named has ceased, and that the nature of all things is unarisen and unceased (MK 18.7). But this means 
only that there are no real entities in the phenomenal world to name, and reality as it is (tattva) is not reflected in language. He does not end the text there, nor does he ever say that silence is required. Nāgārjuna never states that the enlightened have to abandon language, even though ultimate truths are dependent upon conventions (MK 24.10). The enlightened can still use conventional language to state the ultimate truth of emptiness, but they are not misled into thinking that the world is populated with discrete, permanent entities corresponding to our conventional terms.

It is the unenlightened who discriminate discrete objects (vikalpa) and thereby create a false world: to them, if we have a word for something, there must be a distinct reality to be referred to. Thus, they project categories onto the world (prapañca), the process that creates a false world of reified entities (see MK 22.15). But language per se does not need to lead to thinking in terms of discrete entities. To use Bertrand Russell's example, just because we say "it is raining," no one thinks there is an "it" that does the raining - there is just the raining. And the enlightened can react to all nouns the same way. Language is like a map: a map makes what is mapped into a flat world of discrete objects with crisp boundaries, while what is mapped is not actually like that. But this does not mean a map is not useful, and the same is true with language. The enlightened can use words referring to themselves without the seeing the world in terms of "I" or "mine" or "selves" (e.g., YS 33). Nor are labels arbitrary: calling a car a "bottle" or a "pen" is not merely "inappropriate" but wrong.

Most importantly, Nāgārjuna does state how things are "from the point of view of reality (tattvatas)"-i.e., from the point of view of how things really are, and not merely pragmatically from the point of view for gaining the highest fruit (paramaartha). His repeated use of "tattvatas" in the Ratnāvali is most plainly seen as meaning that those statements are unqualifiedly true. It is hard to argue that the basic claim "Reality is empty of self-existence, and phenomena arise dependent upon other phenomena" is not an ultimate truth-from a conventional point of view, the world is populated with distinct entities that are realities unto themselves. So too, the principle "This arises dependent upon that" is not denied even though what arises dependently lacks self-existence and thus is not real (SS 71). The use of conventions does not transform the claim "All this is empty" into a conventional truth. The statement involves our conventions (vyavaharas), as Nāgārjuna states is necessary (MK 24.10; VV 28 Comm.), but the truth about phenomena being empty is a final, unqualified truth, and eminently statable. "Emptiness" is only an indicator (prajñaptir) (MK $22.11,24.18)$ since there is no real, self-existent entity in the world called "emptiness" but the concept can be used to point out something true about reality.

Only part of realizing ultimate truths can be pointed out in words (VV 70 Comm.) since an experiential insight is needed. Realizing that reality is empty of svabhāva is more than merely understanding and accepting the claim-an experiential insight is to realize that the claim is true and to apply it thoroughly to all our experiences and thought, i.e., actually to see the world thoroughly through that perspective. Meditation is required to see that all phenomena in the world are in fact impermanent and conditioned, rather than merely to accept the claim. But "realizing 
ultimate truth" should not be conflated with "ultimate truth"- the experiential insight that reality is empty of self-existence may be free of conceptualizations, but this does not mean that the statement "Reality is empty of self-existence" is not an ultimate truth. Stating an ultimate truth is not the experience showing that it is true, but it is still an ultimate truth about the nature of reality in the final analysis, and it is still statable by recourse to the conventions of a language (MK 24.10). The analytical mind can comprehend the truths, even if a state beyond the analytical mind is needed to become enlightened by internalizing the claim into our perceptions and thoughts. Thus, ultimate truth still involves a conceptual framework but the correct one in terms of emptiness, and to realize the truth we must forego even this conceptual framework. As discussed below, the passage MK 24.8-10 quoted above requires both ultimate truths and going beyond them in an experience. In an earlier Buddhist analogy, it is the difference between the intellectual acceptance of the idea "Water quenches thirst" and actually drinking water (Samyutta Nikāya 2.115). Quenching our thirst by drinking water is not a linguistic event - it thus goes beyond what is expressed, and so the realization is ineffable - but this does not make the statable claim "Water quenches thirst" in any way untrue. Nor is some other unstatable truth learned by drinking water. But we now know it in a way that we did not when relying on the testimony of others - that may change how one views water and understands the claim, but the stated truth remains the same. The realization may require a state of consciousness in which our linguistic abilities are temporarily in abeyance. But even though realizing the final truth is "beyond language" and "ineffable," stating the final truth after the experiential realization of it may still be possible (contra Garfield 1995, 252). The truth is not in some sense ineffable simply because all referents are by definition conventional (contra ibid., 275). Rather, Mādhyamikas could utilize the conventions of a language to state ultimate truths (as MK 24.10 seems to state plainly) if they reject the "mirror" theory of how language operates. And as noted above, Nāgārjuna does reject that theory: there are no "real (sat)" words or referents, but language can still make claims about what is real (i.e., what is dependentlyarisen).

Nothing in Nāgārjuna's writings suggests that silence is the "highest truth." We cannot conclude from what Nāgārjuna actually wrote that "the ultimate truth is that there is no ultimate truth" or that "all truths are merely conventional" or that "there is no such thing as ultimate truth" or that "ultimately, one is left with only conventional truth" or that "the conception of truth supported by the way things really are presents a subtle object of clinging" (Siderits 1989, 213; Garfield and Priest 2003, 10; Westerhoff 2009, 220, 224). We can agree with Mark Siderits when he says "a statement cannot be ultimately true unless there is something ultimately real for it to be about," but Nāgārjuna would reject Siderits' follow-up claim that "nothing is ultimately real unless it has intrinsic nature [i.e., svabhāva]" (2013, 378)-for Nāgārjuna, the that-ness of phenomena in the final ontological analysis is ultimately real, and it is not completely ineffable: some accurate things can be said about it in terms of dependent-arising and the lack of self-existent entities. What is ultimately real is "inexpressible" from a conventional point of view since we think in terms of 
discrete entities and in fact there are none. But from an ultimate point of view, this is not a problem: the enlightened, in rejecting the mirror-theory of language, know there are no "real" entities and can resort to language without projecting a statement onto reality and creating a false world of multiple entities. The ultimate nature of things may be unknowable in the sense that we cannot know it in the way that we know objects in ordinary consciousness - i.e., by making an object out of what is real that we can mentally grasp as a distinct reality. But this does not change the fact that some of the ultimate nature of things can be stated: the phenomena of the world are empty of anything giving them self-existence and instead arise dependently upon other phenomena.

Moreover, if the ultimate truth is not statable, what does Nāgārjuna mean when he says that ultimate truth relies on the conventional? If he had said realizing the ultimate truth relies on conventions, then we could say conventional truths only direct our attention to the ultimate unstable truth, but MK 24.10 states that nirvanna cannot be attained without reaching the ultimate point of view. That is, if we look at the plain language of the passage, three things are mentioned and distinguished: conventional truth, ultimate truth, and realizing enlightenment. Thus, he is distinguishing attaining enlightenment from the two categories of truth (satya [MK24.8]). ${ }^{17}$ Realizing enlightenment may require a wordless experience of the phenomenal world, but this leaves the statements of ultimate truths untouched, and Nāgārjuna never states that ultimate truths cannot be spoken. If ultimate truths were ineffable, he would have said so. (And before the dialetheists say "The description of ultimate reality is that it is indescribable," the point can be made consistently: "The characteristic of the ultimate nature of reality is that is that cannot be described in terms designed for conventional phenomena - it is free of conventional characteristics, and since those are the only characteristics that we know we cannot describe it in positive terms." Calling it "indescribable" is a second-order claim that only eliminates all first-order descriptions; it is not a description of a new phenomenal feature.) There simply are no grounds for dialetheists to claim that ultimate truths are unstatable in Nāgārjuna's thought.

\section{THE EMPTINESS OF EMPTINESS}

A point touched upon in several places above needs to be addressed-the "emptiness of emptiness." The rejection of the four options in verse MK 22.11 introduces the idea: "'Empty,' 'not empty,' 'both,' or 'neither - these should not be said, but they are said only as an indicator (prajñaptir)." Emptiness is itself empty (VV 59) - there is no real, self-existent entity called "emptiness." "Emptiness" is not a new postulated substance or a new object seen or a new substantive "essence" of things. Rather, the term simply describes the state of phenomena as being devoid of anything that would

17 "Realizing satya" can mean either "realizing the reality" or "affirming a truth" since "satya" in Indian thought has dimensions of both reality and truth. That the concept of "satya" does not distinguish reality and truth does lead to the idea that if reality as it truly is is inexpressible then so is truth. But we can distinguish the two components for purposes of analysis. 
give them self-existence or a permanent nature. In MK 24.18, Nāgārjuna calls the concept "emptiness" an indicator dependent upon convention (prajñaptir-upadaya). It differs from most ontological terms only in that there is not even a conventional object as its referent. It differs from most nouns in that there is no phenomenon, either real or empty, to be indicated by the word "emptiness" while most nouns have some (empty) phenomena to be indicated in objective reality. But even so, the unenlightened think that if there is an "indicator" then there is something real in the world to be "indicated." But again, the unenlightened will be misled simply by the term into thinking some real (self-existent) thing is indicated. Nevertheless, like all nouns, the term "emptiness" can be used conventionally to designate something: it indicates the absence of self-existence. The enlightened have gotten beyond projecting our categories onto reality (MK 22.15). They see that "emptiness" is only one of our fabrications employed to inform us of the fabricated nature of all our fabrications. In sum, "emptiness" is simply shorthand for existing without any selfexistence.

Thus, Nāgārjuna treats "emptiness" like any other alleged entity: it too is empty. Hence, the "emptiness of emptiness" is not an esoteric, profound secret doctrine, or a paradox, or anything mysterious at all. ${ }^{18}$ Nor is it a special topic in any of these works. It is not a new, unique ontological claim or a separate doctrine. It is simply the statement that "emptiness" is like any other concept-empty of anything that would make emptiness itself a self-existent reality. In fact, it is an obvious corollary of the basic doctrine. Hence, Nāgārjuna does not need to say much about it, and he does not. Indeed, he never used the phrase "emptiness of emptiness," and yet some scholars consider it his central teaching. "Emptiness" is as much a convention as any other concept - it does not refer to any self-existent entity but is itself empty. It is not a "Cosmic Void" out of which the phenomenal world arises or some new type of selfexistent substantive "essence." Indeed, it is not a phenomenon at all- the term simply designates the true state of the world. To reify the mere absence of anything that could produce self-existence into a reality of any kind would make emptiness into a type of entity - and according to Nāgārjuna, anyone who does this is incurable (asādhyan) (MK 13.8). ${ }^{19}$ The later Mādhyamika Candrakīrti likens the situation to a man who, when being told by a shopkeeper "I have nothing to sell," asks the merchant to sell him that "nothing" (Prasannapada 13.347). ${ }^{20}$

\footnotetext{
${ }^{18}$ Nāgārjuna actually used the abstract noun "Śunyată" very little. He more often used the adjective "śunya" to indicate that things are without self-existence (nihsvabhāva). That lessened the possibility of misconstruing the emptiness of things by reifying "emptiness" into some type of self-existent entity or substance. The ultimate nature of the worldly realm - its "that-ness" (tattva) - is that phenomena are empty, not that there is an ontological entity "emptiness." "Emptiness" merely indicates that nature.

${ }^{19}$ Emptiness and dependent-arising are not themselves entities that are dependently-arisen. If they were, then under Nāgārjuna's analysis this would lead to an infinite regress of dependent arisings. But this does not mean that emptiness is self-existent: it is simply a name for what is dependently arisen (MK 24.18).

${ }^{20}$ Again, being "empty" does not mean being "nonexistent (asat)." Emptiness is not a self-existent reality. It only indicates that phenomena do not have anything that would give them self-existence and
} 
Yet Garfield (2003, 18-19) thinks the emptiness of emptiness leads to the collapse of the distinction of the two truths. However, again, it only means that there is not a self-existent reality called "emptiness" - the term is only an indicator of the true nature of things. The emptiness of "emptiness" is simply the application of Nāgārjuna's philosophy to another concept. Nor does the emptiness of emptiness mean that there is no ultimate reality in the final analysis about which truths can be stated. Any paralogical theory that leads to the dialetheists' conclusion simply must be dismissed as misguided and only confusing our understanding of Nāgārjuna's thought.

\section{NIRVĀNA AND SAMSĀRA}

To generate other paradoxes, the dialetheists rely on nirvāna and samsāra (the cycle of rebirth or the entire realm of rebirths) being the same (e.g., Garfield and Priest 2003, 11). However, Nāgārjuna does not state that nirvāna and samsāra are the same or identical, but only that they are not different in any way:

There is not the slightest difference of cyclical existence from nirvāna. There is not the slightest difference of nirvanna from cyclical existence. The full extent of nirvāna is the full extent of cyclical existence. There is not slightest interval between them (MK 25.19-20). ${ }^{21}$

In his philosophy, saying that two things are "not different"-i.e., that there is no distinction between them (na viśeșanam) — is actually very different from saying they are the "same," and it is important to see why.

In Nāgārjuna's metaphysics, only a truly existing entity can be the same as, or different from, another truly existing entity (e.g., MK 2.21, 6.5; VV 67), i.e., one existing by self-evidence, but all phenomena, including nirvāna and samsāra, are empty of self-existence. Thus, neither nirvāna nor samsāra exist in the way that could make them either the same or different entities. To be the same they have to be real (sat), but in this metaphysics they are not self-existent and hence not real. In sum, things empty of self-existence cannot be related as either the same or different. But "a basic phenomenon (a dharma) that is not dependently-arisen is not seen; thus, a thing that is not empty is not seen" (MK 24.19). If all this is empty, there are no self-

thus make them real (sat) in that sense. This is not to deny that phenomena exist, but only indicates that they exist in another manner-they are dependently-arisen. That is the nature of phenomena.

${ }^{21}$ MK 25.9-10, 13-14 states: "[9] An entity that comes and goes is conditioned and dependent. What is without conditions and is non-dependent is taught to be nirvāna. [10] The Buddha has spoken of relinquishing both becoming and ceasing. Therefore, it is admissible to say that nirvāna is neither an entity nor a non-entity. ... [13] How could nirvāna be both an entity and a non-entity? Nirvāna is uncompounded, but what is an entity and non-entity is compounded. [14] How could nirvāna be both an entity and a non-entity? There can be no existence of these in one place, just as in the case of light and darkness." Being without conditions and non-dependent may suggest that Nāgārjuna is treating nirvāna as self-existent, but here he is only teaching that nirvāna is not an entity (bhāva) or its absence $(a b h \bar{a} v a)$. 
existent entities (MK 16.10, 18.10), and this includes nirvāna and samsāra. Thus, nirvāna and samsāra are neither different nor the same-they are simply not the type of things (i.e., self-existent entities) that could be either different or the same. Indeed, the nature of nirvāna is the same nature as all things - unarisen and unceased (MK 18.7) since only real entities could arise or end. Neither is a real (self-existent) entity, and thus neither is found (YS 4-5). Whatever is the self-nature (svabhāva) of the Buddha is the same nature of the world, i.e., lacking any self-existence (MK 22.16). Since the cosmos (loka) and nirvāna are equally empty of self-existence, how can there be a real difference between them (RV 64)? Since they are not real in the sense of being self-existent, they have no marks (lakșanas) for us to grasp that would differentiate them - only what is real (sat) can have a real mark, and thus from the ultimate point of view everything is without real marks. Again, this does not mean the cosmos and nirvanna are the same but only that they are of the same nature of being empty and thus can be neither identical nor different.

In sum, the fact that nirvāna and samsāra are empty of svabhāva means that they are not different but not that they are the same. Thus, Nāgārjuna never equates nirvāna and samsāra. If Nāgārjuna had wanted to say they were identical, he could have followed the formula of the Prajñāpāramitā Hṛdya Sūtra on emptiness and form (rūpa) and said "samsāara is nirvāṇa, nirvāṇa is saṃsāra" (see Jones 2012, 224-26). Or he could have said they were the same (e.g., samatā) or some other plain statement of identity if that is what he meant. But he is pointing out that nirvāna and samsāra, like everything else, have the same nature: being empty of self-existence. To identify nirvāna and samsāra is simply to miss Nāgārjuna's ontological analysis entirely.

Nirvāna and samsāra being empty of self-existence must be a truth from the ontologically correct ultimate point of view, since conventionally they could not be more different. The claim is also about their ultimate ontological status. Pointing out that nirvāna and samsāra are not the same would not be news to Buddhists-it is claiming that they are not different that is startling. To treat them as the same would be as much an error as treating them as different since we would still be thinking in terms of "real" (self-existent) entities rather than seeing their correct ontological status from the ultimate point of view. To combine parts of two verses: if all entities are empty, what is identical and what is different (MK 25.22-23) ${ }^{22}$

\section{DOES NĀGĀRJUNA HAVE A "VIEW" OR A “THESIS"?}

The final verse of the Mülamadhyamaka-kārikā presents an issue: "I bow to Gautama the Buddha, who through compassion taught the true doctrine for removing all views (drsstis)" (MK 27.30). Is Nāgārjuna claiming that he himself has no views (see MK 13.8)? In addition, in Vigrahavyāvartan̄ he claims to have no thesis (pratijña) (vv.

\footnotetext{
${ }^{22}$ Dialetheists may suggest that this still introduces a paradox-how could something be neither identical nor different? But Nāgārjuna's point can be made without paradox: his metaphysics allows a category (the dependently-arisen) that is outside what could be the same or different (the self-existent); thus, being either the same or different does not exhaust all possible ontological options and so denying both is not paradoxical.
} 
29, 59 Comm.; see also RV 123 and VP 1 Comm.). In the Ratnāvalī, he speaks of propositions (paksas) the same way (v. 104; MK 2.10; YS 50). However, in the same line of the Kārik $\bar{a}$ where he speaks of removing all views, he speaks of the Buddhist doctrine (dharma). In Vigrahavyāvartanī, he also speaks of emptiness as a specific

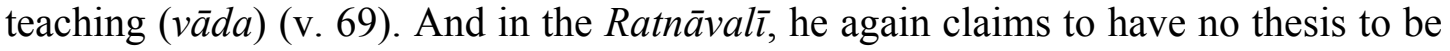
defended but proceeds to discuss the Buddhist doctrine (vv. 60, 62). Thus, when he advances what looks like a metaphysical thesis ("All phenomena are empty of svabhāva") and then denies he has any thesis, it has the paradoxical feel of someone saying "I am not talking right now." This all suggests that he paradoxically claims to have no opinions or positions at all. That is, all views, including Nāgārjuna's, are relegated to the conventional level: from the ultimate point of view, even the claim "Reality is empty of any self-existent entities" has to be rejected as simply another view. In the direct experiential realization of the emptiness of things, all conceptual views must be given up - even seeing the world as empty - since the mind must be freed of all conceptualizations. ${ }^{23}$

However, in the Kārikā Nāgārjuna always connects views to self-existence, suggesting that it only claims about self-existent entities or their absence qualify as “views" (e.g., MK 15.10, 21.14, 24.21, 27.1-2; see YS 14, 23, 43-48, 50-52; RV 104). (To speak of the absence of an entity [an abhava] presupposes that entities [bhavas] exist [MK 15.5; SS16].) In the more informal Ratnāvalī (43-45, 57-58), Nāgārjuna also connects "false views" with the idea that karmic causes do not have effects and "right views" with karmic causes having effects, with right knowledge passing beyond both false and even right views. But he also connects propositions with existence (asti) and nonexistence (nāsti) (RV 46, 50-51, 57-58). Equally important, he also explicitly disconnects emptiness from "views" (MK 13.8), and emptiness is not connected to "is" or "is not" (MK 22.11; R 46, 104-105), i.e., what is sat or asat.

Under this interpretation (which the Tibetan dGe lug pa tradition endorses), Nāgārjuna espoused philosophical positions-i.e., "views" in the non-technical, everyday sense-starting with the first verse of the Kārikā, but he had no views in the technical sense of a position connected to self-existence. If he had a proposition (pakșa), a counter-proposition would be derivable from it, but both would be false (RV 104-105; YS 50). Nāgārjuna is merely "making known" the emptiness of things without being committed to any view; the term "emptiness" is employed merely to inform us of the emptiness of things (MK 22.11, 24.18), not to affirm the existence of a substance existing in the absence of self-existent entities. He can say he has established the emptiness of things in detail while still maintaining that this is not a thesis (VV 59 Comm.) But emptiness cannot be used to refute views (MK 4.8) since it is only the implication arising from other refutations and not a self-existent reality itself.

\footnotetext{
${ }^{23}$ Nāgārjuna treats "theses" as realities. Thus, once there is a thesis, a reason presented later cannot make it "vanish" since it already exists (PV 64 Comm.).
} 
In this way, Nāgārjuna can accept a particular ontology without having a "view." A "view" is not about the "ultimate point of view" but only about having a position requiring self-existent realities. He also speaks of another type of seeing coming from the same root as drssți when he speaks of seeing reality as it really is-"tattvadarśana" (MK 26.10; see MK 21.14, 27.14)—but he does not connect this to a view. Thus, he can assert a doctrine and dispute another one without contradicting himself: he taught a doctrine ( $v \bar{a} d a$ ) of emptiness (VV 69) and a way of viewing (darśana) and the Buddha had a doctrine (dharma), but he has no view (drsți) requiring self-existent realities. The alternative to holding a thesis is not another thesis but another type of doctrine rejecting all theses of self-existence. In sum, the term "drst ti" is a term of art for claims of a svabhāva metaphysics, not every type of "view" in the everyday sense.

For the realization of enlightenment, all views in general must be removed, not merely those connected to self-existence. To realize that emptiness is true-to see reality as it truly is - all points of view or perspectives must be in abeyance. That is, we need to be free of all frameworks, including the framework of emptiness, to see the world as it really is. We must drink the water, not merely have views about its efficacy. One must go beyond understanding statable ultimate truths (see MK 24.10). But the truth of Nāgārjuna's propositions about the emptiness of reality is not in any way doubted. Thus, when Nāgārjuna says "This world is without self-existence" (MK 22.16), there are no qualifications to suggest that it is anything but the absolute truth from the highest point of view_-indeed, it is false from a conventional point of view. So too, when he gives the characteristics of the that-ness (tattva) of true reality (MK 18.9-11), there are no qualifications, and the characteristics are again false from a conventional point of view. MK 26 gives beliefs connected to the standard twelve steps of dependent-arising. But if "drștit," "pratijña," and "pakșa" are terms of art connected to svabhāva, then propositions such as "All phenomena are empty of selfexistence" simply do not qualify as views or theses in Nāgārjuna's technical sense. Stating an ultimate truth involves concepts, but it is not a view (since no metaphysics of self-existence is involved), and so the enlightened can state it without clinging to a view.

Thus, Nāgārjuna does not reject all philosophical propositions but only that directly or indirectly affirm svabhāva and sat. The three important points are first that emptiness is not an entity of any type or its absence, and so we cannot have a "view" about it. Emptiness is the conclusion reached when svabhāva has been rejected, and thus is not itself a "thesis" to be defended. Second, we need to get beyond the conceptualizing mind - including the framework of emptiness - to see reality as it truly is. And third, nothing in his works suggests that ultimate truths are in any way false. Thus, dialetheists cannot claim that Nāgārjuna inconsistently advances the thesis that he has no thesis or the view that he has no view. Within his metaphysics, his positions are not theses or views since the latter must presume the reality of selfexistence. 


\section{CONCLUSION}

In sum, the dialetheists are wrong in their exposition of Nāgārjuna's way of thinking. To make his thought appear paradoxical, they have to ascribe claims to him that he never made. Moreover, simply because we can state his claims paradoxically if we choose to do so does not mean that he actually thought that way. But Nāgārjuna's arguments presume the basic laws of logic and are free of genuine paradoxes. This is not to say that his arguments are successful, but only that they can be consistently expressed. We can understand his points without importing modern theories of nonconventional alternative logics or accepting that some irresolvably contradictory statements actually make intelligible claims. Nāgārjuna was trying to show by a rather rigorous conceptual analysis and the use of classical logical reasoning that any metaphysical system that affirms self-existing, permanent entities leads to inconsistencies with what we see actually happening in the world and thus cannot be accepted. Indeed, logic and the avoidance of contradictions are absolutely central to how his arguments proceed.

Paradox can be added to Nāgārjuna's thought only by presenting his ideas vaguely rather than clearly. This may be true more generally of the dialetheists' method. To take one of Graham Priest's examples $(2004,28)$, consider the situation when I am standing in a doorway between two rooms with one foot in each room. We can state this situation paradoxically:

- "I am in this room and not in this room."

- "I am in two rooms at once."

But these do not state the actual situation clearly and fully. And we have the conceptual resources to state the true situation clearly and completely without paradox:

- "I am partially in one room and at the same time partially in another."

Genuine paradox occurs only if we claim:

- "I am entirely in two different rooms at the same time."

But this statement is not only paradoxical, it is false and no one believes it or thinks that way. Since the correct situation can be stated clearly and consistently, to get a paradox one must confuse the situation with less exact statements. And the same applies to the situation with Nāgārjuna's seemingly paradoxical passages: we do not have to torture what he stated to see that he was being entirely consistent and logical within his framework of beliefs.

By artificially introducing paradoxes, the dialetheists make Nāgārjuna's ideas seem less intelligible than they are. Of course, it is exciting to add paradox to someone's thought: it makes something seem more profound and mysterious. And we do have difficulty expressing ideas at the edge of our knowledge that transcends the 
ordinary or presenting a new way of looking at things. ${ }^{24}$ More generally, it is certainly more fun to say "Never say never!" rather than the consistent "Always leave all possibilities open." But claiming "There is no ultimate truth, and that is the ultimate truth" or "The inherent nature of things is that they have no inherent nature" is not harmless when presenting how Nāgārjuna argued-not only are such claims confusing, they distort what Nāgārjuna actually stated without paradox and destroy how his arguments actually proceeded. Simply because we can today restate his doctrines as paradoxes does not mean that that is how Nāgārjuna actually thought. Nāgārjuna's apparent paradoxes can be easily defused, and nothing suggests that any aspect of his thought can only be expressed in inconsistent terms.

\section{ACKNOWLEDGEMENTS}

The author would like to thank the two reviewers for their careful reading of the article and their suggestions.

\section{ABBREVIATIONS}

Comm. Nāgārjuna's self-commentary

DGP Yasuo Deguchi, Jay L. Garfield, and Graham Priest

MK Mūlamadhyamaka-kārikā (Fundamental Verses of the Middle Way)

RV Ratnāvalī (Jewel Garland of Advice)

SS Śnyatāsaptati-karikā (Seventy Verses on Emptiness)

VP Vaidalyaprakarana (Pulverizing the Categories)

VV Vigrahavyāvartanī (Overturning the Objections)

YS Yuktișaștika-kārikā (Sixty Verses on Argument)

\section{REFERENCES}

Deguchi, Yasuo, Jay L. Garfield, and Graham Priest (2008), "The Way of the Dialetheist: Contradictions in Buddhism", Philosophy East and West 58.3: 395402.

- (2013a), "How We Think Mādhyamikas Think: A Response to Tom Tillemans", Philosophy East and West 63.3: 426-435.

\footnotetext{
${ }^{24}$ Virtually anything in mysticism can be stated paradoxically-e.g., "the highest form of wisdom is ignorance" (i.e., one must empty one's mind of all conventional knowledge to gain mystical knowledge). In addition, mystics have used the form of paradox for soteriological purposes - the shock value of saying the absurd. But what mystics say can also be defused and the content can be presented consistently (see Jones 2016, chapter 7).
} 
- (2013b), "Does a Table Have Buddha-Nature? A Moment of Yes and No Answer! But Not in Words or Signs! A Response to Mark Siderits", Philosophy East and West 63.3: 387-398.

Garfield, Jay L. (1994), "Dependent Arising and the Emptiness of Emptiness: Why did Nāgārjuna Start with Causation?", Philosophy East and West 44.2: 219-250.

- (1995), The Fundamental Wisdom of the Middle Way: Nāgārjuna's Mūlamadhyamakakārikā (New York: Oxford University Press).

Garfield, Jay L. and Graham Priest (2003), "Nāgārjuna and the Limits of Thought", Philosophy East and West 53.1: 1-21. (Reprinted in Priest 2002.)

- (2009), "Mountains are Just Mountains", in Mario D'Amato, Jay L. Garfield, and Tom J. F. Tillemans (eds.), Pointing at the Moon: Buddhism, Logic, Analytic Philosophy (New York: Oxford University Press), 71-82.

Jones, Richard H. (1993), "The Nature and Function of Nāgārjuna's Arguments”, in his Mysticism Examined: Philosophical Inquiries into Mysticism (Albany: State University of New York Press), 79-97.

- (2011), Indian Madhyamaka Buddhist Philosophy after Nāgārjuna, vol. 1 (New York: Jackson Square Books).

- (2012), The Heart of Buddhist Wisdom: Plain English Translations of the Heart Sutra, the Diamond-Cutter Sutra, and Other Perfection of Wisdom Texts (New York: Jackson Square Books).

- (2014), Nagarjuna: Buddhism's Most Important Philosopher, rev. ed. (New York: Jackson Square Books).

- (2016), Philosophy of Mysticism: Raids on the Ineffable (Albany: State University of New York Press).

Matilal, Bimal Krishna (1988), The Character of Logic in India (Albany: State University of New York Press).

Priest, Graham (2002), Beyond the Limits of Thought, 2nd ed. (New York: Cambridge University Press).

- (2004), "What's So Bad About Contradictions?", in Graham Priest, JC Beall, and Bradley Armour-Garb (eds.), The Law of Non-Contradiction: New Philosophical Essays (New York: Clarendon Press, 2004), 27-38.

- (2006), In Contradiction: A Study of the Transconsistent, 2nd ed. (New York: Oxford University Press).

Siderits, Mark (1989), "Thinking on Empty: Madhyamaka Anti-Realism and the Canons of Rationality", in Shlomo Biderman and Ben-Ami Scharfstein (eds.), Rationality in Question: On Eastern and Western Views of Rationality (New York: E. J. Brill, 1989), 231-249.

- (2003), "On the Soteriological Significance of Emptiness", Contemporary Buddhism 4.1: 9-23.

- (2008), "Contradiction in Buddhist Argumentation", Argumentation 22.1: 125133.

- (2013), "Does a Table Have Buddha-Nature?", Philosophy East and West 63.3: 373-186. 
Tillemans, Tom J. F. (2009), "How do Mādhymikas Think? Notes on Jay Garfield, Graham Priest, and Paraconsistency", in Mario D'Amato, Jay L. Garfield, and Tom J. F. Tillemans (eds.), Pointing at the Moon: Buddhism, Logic, Analytic Philosophy (New York: Oxford University Press), 83-100.

- (2013), “'How do Mādhymikas Think?' Revisited”, Philosophy East and West 63.1: 417-425.

Westerhoff, Jan (2009), Nāgārjuna's Madhyamaka: A Philosophical Introduction (New York: Oxford University Press). 